ppi $201502 Z U 4645$

Esta publicación científica en formato digital es continuidad de la revista impresa ISSN-Versión Impresa 0798-1406 / ISSN-Versión on line 2542-3185Depósito legal pp $197402 Z$ U34

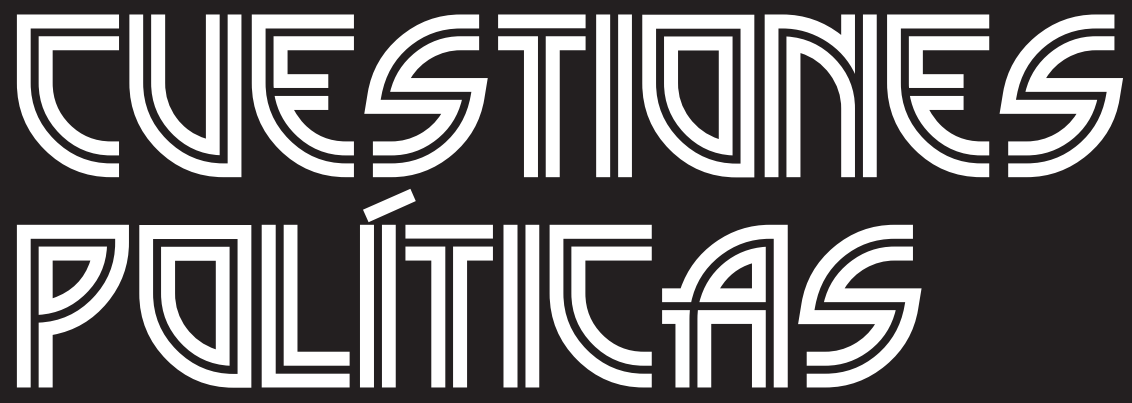

Instituto de Estudios Políticos y Derecho Público "Dr. Humberto J. La Roche" de la Facultad de Ciencias Jurídicas y Políticas de la Universidad del Zulia Maracaibo, Venezuela
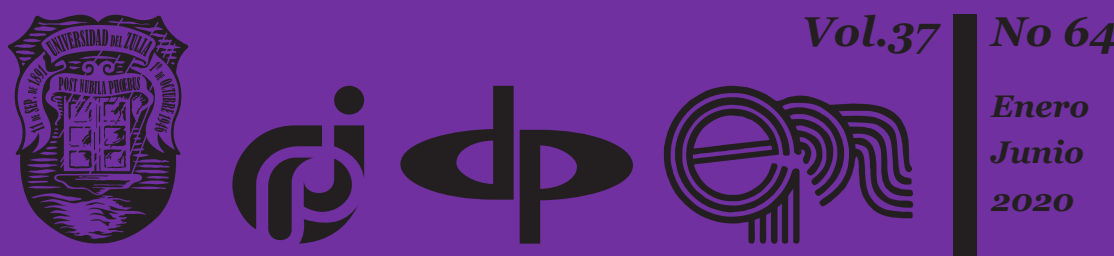


\title{
Correlation of Law and Order in Society
}

\author{
Gabdrakhman H. Valiev * \\ Sergey V. Kondratyuk ** \\ Natalia A. Prodanova *** \\ Irina A. Babalikova **** \\ Kermen I. Makaeva $* * * *$ \\ Innokentiy I. Baishev *****
}

\begin{abstract}
The problem of the relationship of law and order is relevant to any modern society. The article tries to analyze this relationship, taking into account judicial, police and other activities. The named concepts are closely interconnected, but are not identical. They are correlated as cause and effect: there is a rule of law, there is no rule of law. One suggests the other. The rule of law as concrete reality logically precedes the rule of law as a doctrine, the connection here is hard, causal. The process is one. Law and order: a real indicator of the state of legality, reflects the degree of compliance with the laws, the requirements of all legal regulations. It is concluded that the rule of law is the end result of the implementation of legal requirements and, at the same time, the objective of legal regulation, since it is for the formation and maintenance of the rule of law that laws are issued, thus like other regulatory legal acts, various institutions and bodies and, above all, the justice system, the control system, various human rights organizations
\end{abstract} and social movements.

Keywords: legality; law; rule of law; modern democracy; citizen liberties.

\footnotetext{
* Kazan Federal University, Kazan Russia. Email: valiev_19@mail.ru.

** Togliatti State University, Togliatti Russia; Email; uni.state-2019@yandex.ru.

*** Plekhanov Russian University of Economics, Moscow, Russia; https://orcid.org/oooo-0oo1-51402702. Email: prodanova-oo@inbox.ru.

**** Kuban State Agrarian University named after I.T. Trubilin, Krasnodar, Russia. https://orcid.org/ooooo001-5570-2964. Email: babalikova_irina@yahoo.com.

***** Kalmyk State University named after B. B. Gorodovikova, Elista, Russian Federation. https:// orcid.org/oooo-ooo1-7516-7313. Email: makaeva.kermen@yandex.ru.

****** North-Eastern Federal University named after M.K. Ammosov, Yakutsk, Russia. https://orcid. org/oooo-0oo2-0231-9176. Email: baishev@yahoo.com.
} 
Gabdrakhman H. Valiev, Sergey V. Kondratyuk, Natalia A. Prodanova, Irina A. Babalikova,

Kermen I. Makaeva y Innokentiy I. Baishev

54

Correlation of Law and Order in Society

\section{Correlación de Ley y Orden en la Sociedad}

\section{Resumen}

El problema de la relación de la ley y el orden es relevante para cualquier sociedad moderna. El artículo intenta analizar esta relación, teniendo en cuenta las actividades judiciales, policiales y de otro tipo. Los conceptos nombrados están estrechamente interconectados, pero no son idénticos. Se correlacionan como causa y efecto: hay un estado de derecho, no hay estado de derecho. Uno sugiere el otro. El estado de derecho como realidad concreta precede lógicamente al estado de derecho como doctrina, la conexión aquí es dura, causal. El proceso es uno. Ley y orden: un indicador real del estado de legalidad, refleja el grado de cumplimiento de las leyes, los requisitos de todas las normas legales. Se concluye que el estado de derecho es el resultado final de la implementación de los requisitos legales y, al mismo tiempo, el objetivo de la regulación legal, ya que es para la formación y mantenimiento del estado de derecho que se emitan las leyes, asi como otros actos legales regulatorios, varios instituciones y organismos y, sobre todo, el sistema de justicia, el sistema de control, diversas organizaciones de derechos humanos y los movimientos sociales.

Palabras clave: legalidad; ley y orden; estado de derecho; democracia moderna; libertades ciudadanas.

\section{Introduction}

The rule of law logically precedes the rule of law, the connection here is tough, causal. It is no coincidence that in both the everyday socio-political vocabulary they put both of these concepts together: strengthening the rule of law and the rule of law or violating the rule of law. Law and order is a real indicator of the state of legality, it reflects the degree of compliance with laws. The rule of law is the result of legality. The requirements of legality in the law enforcement process lead to a stable legal relationship, providing a legal order. Therefore, law, legal relations, law and order is the result of the rule of law in its qualitative parameters. This is not about any law, legal relationship, order, but about their certain qualitative characteristics.

Differences in the content of law and order depend on its parties (elements): substantive (carriers of legality - something that must comply with legal requirements); subjective (the composition of subjects covered by the obligation to comply with legal requirements and the right to demand such compliance from other persons); normative (a circle of legal requirements that are binding). Changing these aspects of legality determines a different amount of its content in specific historical conditions, increasing or decreasing its role in society. 
Law and order exist under any political regime and their specific content is socially determined and manifests itself in the normative, subject and subjective aspects of legality. All this objectively determines the fact that formal law and order under certain conditions can turn into their opposite, becoming "elevated to law by lawlessness."

\section{Methodology}

In the legal sphere, it is difficult to find phenomena that are more interconnected than law and order. This led to the fact that for a long time no distinction was made between them and they were used as equivalent concepts. The similarity and difference in interaction is important to trace, because it is of great practical importance, both for strengthening the rule of law and strengthening the rule of law.

I would like to emphasize once again that when analyzing and describing law and order it is very important to take into account the social ties and relations in which they are studied (Mullakhmetov et al., 2018). Taken on their own, they mean absolutely nothing.

In the study of the means of power and the ways of exercising state power, one connection is taken. Here, legality acts as a method of state leadership of society. And not the legal method itself, but its condition, qualitative characteristics. These points must be taken into account when comparing the rule of law and legality. Legal aspects of the problem of law and order have become the subject of scientific research relatively recently (Galuzin, 2008). An important role in the law enforcement system is played by international legal treaties, agreements, etc. These documents include: The 1948 Universal Declaration of Human Rights (Ageev, 2013); International Covenant on Economic, Social and Cultural Rights, 1976 (Matveev, 2011); International Covenant on Civil and Political Rights of December 16, 1966 (International Covenant "On Civil and Political Rights"); The Optional Protocol to the International Covenant on Civil and Political Rights of 1966 (Optional Protocol to the International Covenant on Civil and Political Rights) and a number of other acts. The norms of international law enshrined in them formed the basis of the provisions of the Constitution and legislation of the Russian Federation regarding the fundamental rights of citizens and their restrictions in the field of public safety (Akhmetshin et al., 2018). 
Gabdrakhman H. Valiev, Sergey V. Kondratyuk, Natalia A. Prodanova, Irina A. Babalikova, Kermen I. Makaeva y Innokentiy I. Baishev

\section{Results and Discussion}

In the legal system of society there are three categories, the ratio of which is advisable to trace. Their internal relationships are so complex and diverse that it is difficult to grasp the dependencies and make a distinction. These categories are law, law and order. They have much in common, the degree of their interpenetration and dependencies is too high. The properties of these categories pass from one quality to another of the analyzed phenomena. So, for example, orderliness, on the one hand, is the result of the exercise of law and legality, and on the other hand, their most important property. For a long time, the implementation of laws was invested in the content of law and order and therefore no distinction was made between them.

These categories are formed on the same principles, are interconnected with state power, they have a single state-will content and interests. They are associated with rights, freedoms and duties, responsibility of citizens, subjects of law, have formal regulatory certainty, etc. But this does not deny, but assumes the existence of fundamental differences that determine their quality independence.

1. Law, legality, law and order - categories different in content and nature:

law - the state will and interests established by law, their objectified form, having normative certainty;

legality - a qualitative aspect of the legal activities of legal entities and their behavior; property of a method, principle, mode;

law and order - the state of the legal life of society, an ordered system of legal relations and their properties.

2. They are the various stages in the implementation of the will and interests of the authorities and the people:

law - the initial stage, as the formulation of the will and interests into binding rules for all, their objectification;

Legality - the realized law, the legal quality of normative and legal implementation acts, the process of their implementation;

law and order - the law implemented, the will and interests of state power and the people realized.

The level of development of legal matter is different: the initial moment, movement and the final result. 
3. They carry a different legal functional burden. Law, laws - the legal basis of law and order, legality - a means of establishing it, law and order the result of the exercise of law and legality, streamlining social life.

Law and rule of law are original tools that allow solving assigned tasks and achieving goals. There is a rule of law - there is a rule of law. There is no law - there is lawlessness, arbitrariness, anarchy. Therefore, the strength and perfection of law and order are directly dependent on the law, on this quality of the rule-making and law-enforcement process.

4. Their connections and dependencies are different.

If legality acts as a cause, then the rule of law is a consequence.

If in the analysis of legality we are dealing primarily with quantitative and qualitative characteristics, then when considering the rule of law - with states and their quality,

If law, laws act as an opportunity to regulate social relations, then legality is the reality of their implementation, and the rule of law is implementation, reality. If legality is the quality of rule-making and lawenforcement processes, then in the law and order it is one of the essential manifestations of the state (Ryabtsev and Gulyagin, 2016).

Each of the forms of manifestation of legality has its own specific consequences. They cannot be included in the concept of legality, just as the cause and effect cannot be mixed.

The requirements of the rule of law in the rule-making process determine a harmonious and ramified system of democratic and fair legislation, law. The requirements of the rule of law in the process of law enforcement lead to a stable legal relationship and ensure legal order. Therefore, law, legal relations, law and order is the result of the rule of law in its qualitative parameters. These characteristics pass to law, legal relations, law and order. Therefore, we are not talking about any law, legal relationship, order, but about their specific qualitative characteristics. Legality acts as a kind of legal means in the hands of state power and the people to establish and maintain law and order. This is the condition for its functioning, which determines all the essential characteristics of the rule of law as a property and state of public life. This property clearly manifests itself in comparison with its opposites, such as crime, delinquency, abuse, illegal regulatory and enforcement acts, arbitrariness, lawlessness, etc.

Therefore, when analyzing the rule of law, it is important to highlight not only its basis, form, structure, connections and relationships, but also 
Gabdrakhman H. Valiev, Sergey V. Kondratyuk, Natalia A. Prodanova, Irina A. Babalikova, Kermen I. Makaeva y Innokentiy I. Baishev

that all these legal issues meet certain requirements and have the quality of legality. This is one of the fundamental differences between law and order and legal arbitrariness.

Legality provides (aimed at ensuring) the universality of law, and the rule of law is the result of such provision. The rule of law, notes S.S. Alekseev, "being the crown, the final result of the operation of law, it seems to close the chain of basic socio-political phenomena from the field of legal superstructure (lawfulness - legality - law and order)" (Alekseev, 1982).

In this regard, it would not be entirely accurate to identify the rule of law with the activities of people, with their legitimate actions, with their relations developing on the basis and within the framework of the law.

With this identification, the semantic nuances of the concepts of "legality", "law and order" are difficult to identify.

The content of the rule of law is the orderliness of public relations, expressed in the lawful behavior of their participants. Therefore, when participants in regulated legal relations reconcile their behavior with subjective rights and legal obligations, then the rule of law develops.

As you can see, the rule of law directly adjoins the law, expressed in the requirements of its observance, the rule of law - to exercise subjective rights, fulfillment of legal duties.

Such a line of reasoning leads to the need to clarify the essence of the concept of "lawful behavior".

First of all, one must see that not all human behavior has legal significance.

"The right," notes V.N. Kudryavtsev, "regulates not everything, not any behavior of people, but only some (certain) types of behavior that have important social significance. Being enshrined in a legal norm (in a positive or negative form), such behavior becomes legally significant, i.e. causes certain consequences, it is protected and provided by the state" (Kudryavtsev, 1996).

From this we can conclude: socially significant behavior of people should be considered as legal behavior, if it is provided for by the norms of law and entails legal consequences.

Lawful behavior is a type of legal behavior.

Such behavior of subjects can only be discussed to the extent that it coincides with the model fixed in the legal norm, i.e. is in the field of legal regulation, this is, firstly. 
Secondly, lawful behavior, as a rule, socially useful behavior, is based on the observance, execution and use of legal norms.

Thirdly, the judgment that the lawful behavior of an individual is based on a positive attitude towards legal norms and principles does not seem accurate.

Indicative in this regard are judicial litigation, unjustified legal claims, the formal fulfillment of legal duties, etc. (Pelvitskaya et al., 2018).

At the same time, lawful behavior does not cease to be such in connection with the fact that its subjective side is socially reprehensible motives. Of course, if the latter are not expressed in acts prohibited by law.

In this regard, in the legal literature the concept of "lawful behavior" is covered as necessary and desirable and socially acceptable.

\section{Conclusion}

So, lawful behavior is a socially necessary, desirable or acceptable from the point of view of the interests of society, the behavior of legal entities that meets the requirements of legal norms, is guaranteed and protected by the state.

The legal literature provides more concise formulations. V.K. Babaev writes: "Lawful behavior of an individual is behavior that complies with the requirements of legal norms" (Babaev, 2016).

As you can see, the nature and degree of awareness of motivation for legitimate behavior is its subjective side (Mirzagitova et al., 2017).

The objective side is the compliance of lawful behavior with the rule of law. We are talking about external forms of manifestation of personal motivation, consistent with legal requirements. Consequently, the lawful behavior of citizens (organizations) is distinguished by its specificity, which must be taken into account both in law-making and in law enforcement.

The rule of law should be distinguished from a close, but not identical to it phenomenon - public order, which, like the rule of law, is characterized by organization and orderliness of public relations.

Public order is the order of social relations that develops as a result of the action of all social norms, i.e. legal norms, moral norms, as well as customs, corporate norms (Bezrukov, 2016).

In other words, public order is a state of regulation of social relations based on the implementation of all social norms. 
Gabdrakhman H. Valiev, Sergey V. Kondratyuk, Natalia A. Prodanova, Irina A. Babalikova, Kermen I. Makaeva y Innokentiy I. Baishev

60

Correlation of Law and Order in Society

In the scientific and educational literature, it is noted that the concept of "public order" has a double meaning: in the broad, as mentioned above, and in the narrow - as an order that develops in public places (streets, squares, parks, places of spectacular, entertainment events, etc.). This approach is justified, serves to solve practical problems by law enforcement agencies. We are talking about criminal law and administrative security in parks, on highways, train stations, marinas, airports, cultural and entertainment establishments, etc. This procedure is associated with ensuring a calm atmosphere, helping to ensure normal working conditions and recreation of citizens for the activities of state bodies, public organizations, enterprises and institutions. Such an understanding of public order (narrow meaning) is spoken of in legal acts defining the forms and methods of activity of law enforcement bodies.

In conclusion, we note that the rule of law is a necessary prerequisite and foundation of civil society. Today, the problem of law and order is especially relevant, since it is on this basis that the socio-economic, political, and cultural spheres of society and the state are based.

\section{Bibliographic References}

AGEEV, Valerievna Nadezda. 2013. The legitimacy of limiting the rights and freedoms of public servants in the Russian Federation: legal assessment of the Constitutional Court. In: Legal Studies, No. 1, pp. 166-189.

AKHMETSHIN, Ekaterina Mikhail; VASILEV, V. L; GAPSALAMOV, A. R; PAVLYUK, A. V; SHARIPOV, R. R; GATIN, R. G. 2018. Formation of Institutional Arrangement of Economic Security Improvement of Russia: Task Definition. In: Paper presented at the Proceedings of the 31st International Business Information Management Association Conference-Innovation Management and Education Excellence through Vision 2020, 6395-6401.

ALEKSEEV, Svetlana Sergey .1982. General theory of law (vol. 1). Bulletin of the Supreme Court of the Russian Federation. Moscow, Russia.

BABAEV, Valery Kattusi. 2016. The theory of state and law: a textbook for bachelors (3rd ed.), Yurayt Publishing House. Moscow, Russia.

BEZRUKOV, Albina Valerievna. 2016. Law and order: essence, correlation and constitutional legal dimension. In: Russian Law Journal, No. 2, pp. 5967. 
GALUZIN, Alexandra Faira. 2008. Legal security and its principles. Publishing House of R. Aslanov “Legal Center Pres”. Moscow, Russia.

INTERNATIONAL COVENANT OF DECEMBER 16. 1966. "On Civil and Political Rights". (1994). Bulletin of the Supreme Court of the Russian Federation, 12.

KUDRYAVTSEV, Valery Nikolaevna. 1996. Thelaw. Act. Responsibility. Bulletin of the Supreme Court of the Russian Federation. Moscow, Russia.

MATVEEV, Paul Alexandra. 2011. The concept of the family in Russian law. In: Legal Bulletin of the Kuban State University, No. 3, pp. 10-17.

MIRZAGITOVA, Anatolevna Leonid; ILIN, A. G; IBATOVA, A. Z. 2017. The role of knowledge and pedagogical communication in modern society. Quid-investigacion ciencia y tecnologia, No.1(SI), pp. 1613-1617.

MULLAKHMETOV, Katrin Srgey; SADRIEV, R. D; BIKULOV, R. A; AKHMETSHIN, E. M. 2018. Sociocultural factors of transforming administration and control in the management of economic and social systems under modern conditions. Paper presented at the Proceedings of the 31st International Business Information Management Association Conference, IBIMA 2018: Innovation Management and Education Excellence through Vision 2020, pp. 3573-3581.

OPTIONAL PROTOCOL TO THE INTERNATIONAL COVENANT ON CIVIL AND POLITICAL RIGHTS OF DECEMBER 19. 1966. (1994). In: Bulletin of the Supreme Court of the Russian Federation, No. 12.

PELVITSKAYA, Elena Petrov; GUBAREVA, A. V; KOVALENKO, K. E. 2018. Place of judicial practice in sources of environmental law of the Russian Federations. QUID-Investigacion ciencia y tecnologia, 2(SI), pp. 129-132.

RYABTSEV, V. P; GULYAGIN A. Yu. 2016. Legality as a subject of law enforcement in the field of administrative jurisdiction. In: Russian Justice, No.10, pp. 2-7. 

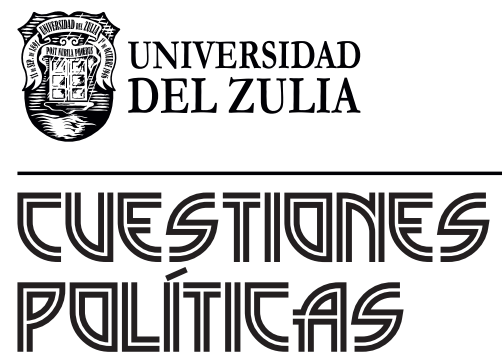

Vol. $37 \mathrm{~N}^{\circ} 64$

Esta revista fue editada en formato digital y publicada en junio de 2020, por el Fondo Editorial Serbiluz, Universidad del Zulia. Maracaibo-Venezuela 